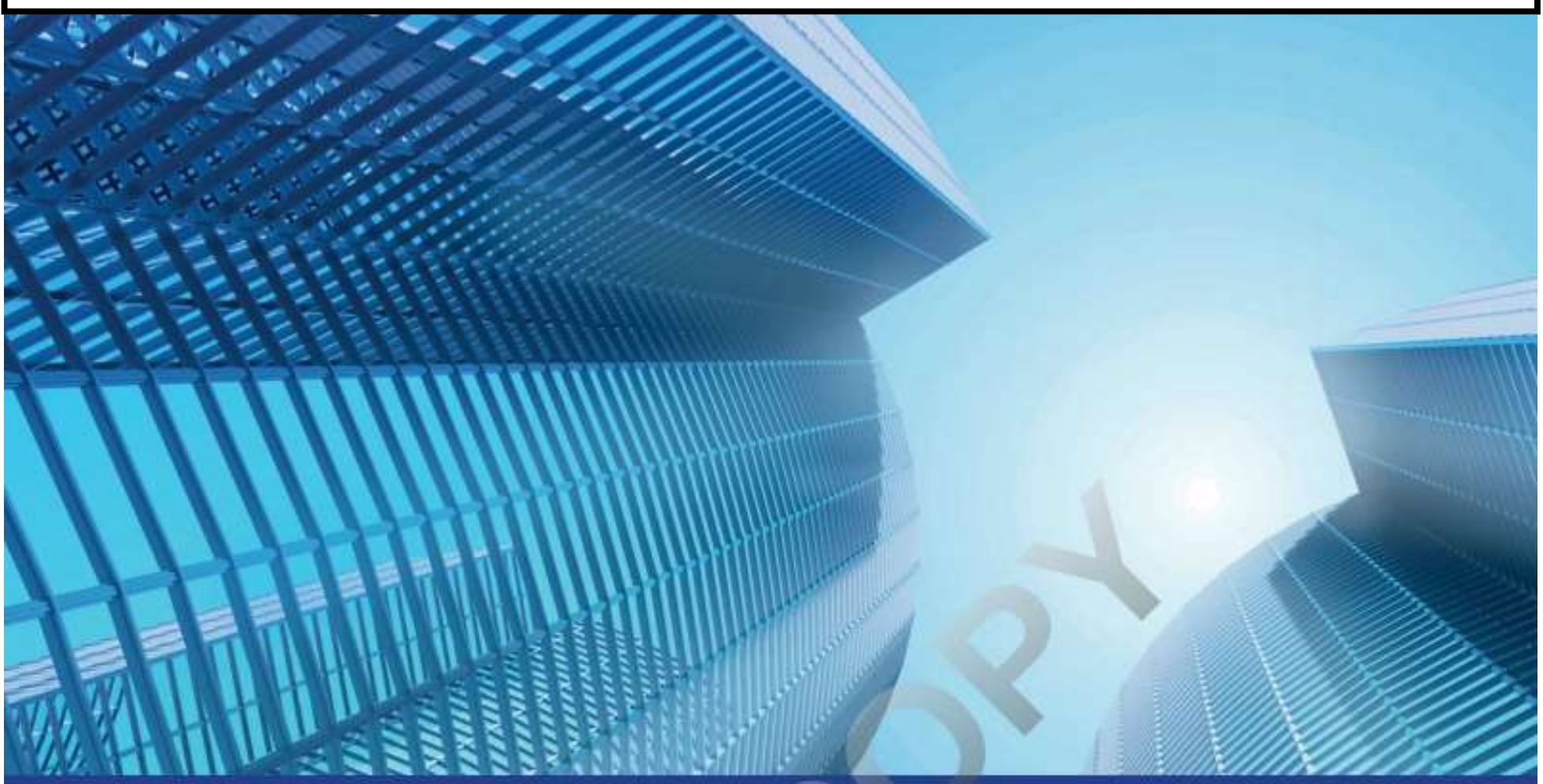

\title{
CONTEMPORARY RESEARCH ON BUSINESS AND MANAGEMENT
}
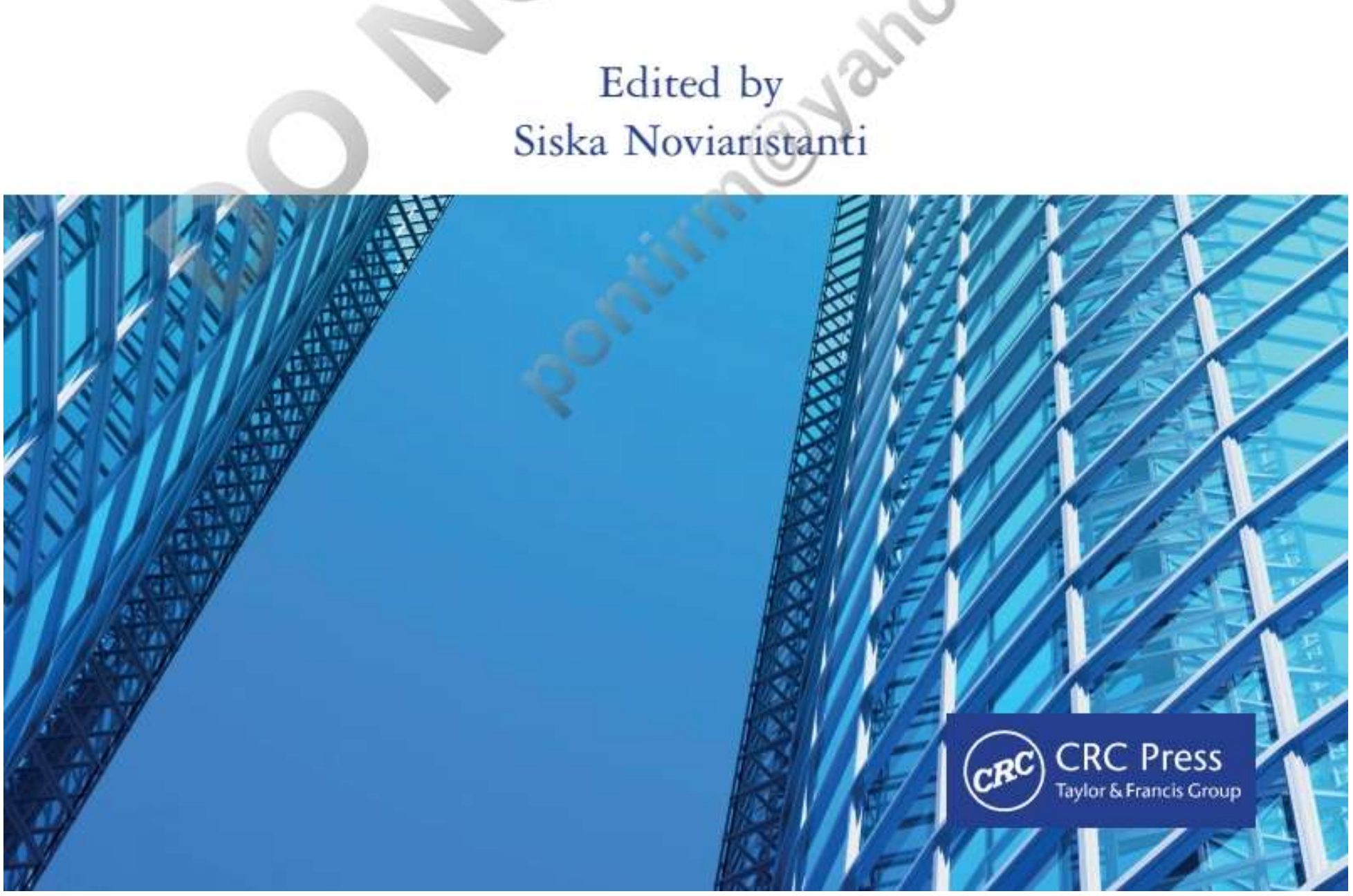


\section{Contemporary Research on Business and Management}

Edited by

Siska Noviaristanti

School of Economic and Business/Telkom University, Bandung, Indonesia 
CRC Press/Balkema is an imprint of the Taylor \& Francis Group, an informa business

C 2021 Taylor \& Francis Group, London, UK

Typeset by Integra Software Seryices Pvt. Ltd., Pondicherry, India

All rights reserved. No part of this publication or the information contained herein may be reproduced, stored in a retrieval system, or transmitted in any form or by any means, electronic, mechanical, by photocopying, recording or otherwise, without written prior permission from the publisher.

Although all care is taken to ensure integrity and the quality of this publication and the information herein, no responsibility is assumed by the publishers nor the author for any damage to the property or persons as a result of operation or use of this publication and/or the information contained herein.

\section{Library of Congress Cataloging-in-Publication Data}

Applied for

Published by: CRC Press/Balkema

Schipholweg 107C, 2316XC Leiden, The Netherlands

e-mail: Pub.NL@taylorandfrancis.com

www.routledge.com - www.taylorandfrancis.com

ISBN: 978-0-367-47166-8 (Hbk)

ISBN: 978-1-003-03598-5 (eBook)

DOI: $10.1201 / 9781003035985$

https://doi.org/10.1201/9781003035985 


\section{Table of contents}

Preface

Conference committee

Scientific committee

xiii

Advisory board

Warehouse selection using center-of-gravity method in minimizing transportation cost

Marketing strategy in postgraduate Tangerang Muhammadiyah University to improve human resources in Tangerang city

P. Susilo, C. Kurniastuti \& D. Hadiwijaya

Examining a psychological sense of brand community in iPhone users

O.O. Sitepu \& N. Sobari

Factors contributing to employee performance

E. W. Silitonga \& J. Sadeli

Service-quality enhancement of the good willie barber shop using importance-performance analysis and business model re-modelling

R. H. Putri \& A.A. Cholil

Exploring big data adoption by Indonesian start-ups

D. Riswantini, U.S. Putro \& M. Siallagan

Analyzing the effect of job satisfaction and work-life enrichment as factors toward employee turnover intention: A case in PT XYZ

M. Raynaldi \& A. Satrya

SBH strategic planning of new business development

A.A. Adyana \& A.D. Hanani

Creating financial statements for performance evaluation at the MSME ENF

P. Kusumapratiwi \& L. Sudhartio

Effect of work autonomy on innovative work behavior in the application and game developer sector: Psychological flow as mediator

P.D. Lestari \& A. Satrya

Physical evidence development of SME woven coffee through business coaching

D.D. Sindudipoera \& S.K. Widhaningrat

Increasing revenue using a marketing plan on a geotracker product based on the business coaching method

J. Haryanto \& H. Suhaimi 
The effect of fun at work on turnover intention and organizational citizenship behavior with affective commitment as a mediating variable among millennial employees in the digital creative industry

\section{S.G. Oktariza \& P.M. Desiana}

The effect of role overload on organizational citizenship behavior of national standardization agency employees mediated by employee exhaustion and moderated by supervisor autonomy support

D.N. Sari \& P.M. Desiana

Strategies to increase liquidity and productivity in divisi tanaman semusim PTPN IX: A case study

E.R. Tholib \& A.D. Hanani

The restructuring of state-owned enterprises: A case study in an Indonesian trading company

O. Laura A. \& R. Rokhim

Analysis of the role of work-family balance mediation in the relationship between social support and job satisfaction of offshore workers in the oil and gas industry

I.O. Simanjuntak \& P.M. Desiana

The impact of push, pull, and mooring factors toward customer switching intention on internet service providers in Indonesia

T. Kusumastiti \& T.E. Balqiah

The employment relationship, turnover, and organizational performance in garment

factories: A conceptual paper

L. Damaryanti \& $P$. Wulandari

Analysis of the effect of servicescape and coffee quality on customer satisfaction using an experiential marketing and brand identity approach in Anomali Coffee, Senopati Jakarta as a case study

\section{A.L. Larasati \& A.Z. Afiff}

The influence of school climate, social-emotional learning, and proactive personality on job satisfaction of PAUD teachers mediated by teaching efficacy in Depok, West Java, Indonesia F.A. Fanhandaya \& A. Satrya

The impact of working capital management on a company's performance: Evidence from manufacturers in ASEAN-5

R.U. Hutapea \& M. Ulpah

The influence of self-efficacy on reduced audit quality practice with burnout as a mediator on public auditors

D. R. Angraini \& A. Satrya

The influence of ownership and board size on the performance of state-owned enterprises listed on the Indonesia stock exchange during the period 2013-2018

S.A. Sutomo \& J. Jahja

The role of individual and situational factors to whistleblowing in public sectors

D.C. Budiutami \& A. Aprilianti

Japanese cultural festival behavioral intention based on attendees' co-creation, perceived value, and satisfaction

M. Larasati \& T.E. Balqiah

Commitment and identification in the Millennial employee: The perceptions of organizational and supervisor support

Innayatussolihah \& E.S. Pusparini 
The influence of entrepreneurial \& marketing orientation to strategic learning capability and SME performance automotive industry in Indonesia - A conceptual framework

M.Z. Azizi \& L. Sudhartio

The effect of human resource management practices on turnover intention of the auditor in $\mathrm{XYZ}$ institution in Indonesia: The mediating role of burnout

A.W. Pratiwi \& A. Satrya

Determinant of financial inclusion in Indonesia

C. Azzahra \& R.A. Kasri

Factors influencing customers' continued mobile app use intention from the internet service provider perspective: Information adoption model Y. Pitasari \& S. Rahayu H.H.

The effect of fun at work and social support towards organizational citizenship behavior with work engagement as a mediation variable at PT Telkom Indonesia (regional II)

D.C. Ginbreta \& P.M. Desiana

Continuance usage intention in mobile payment services

N. Fitria \& N. Sobari

Influence of healthy lifestyle, health concerns, environmental concern, and product quality toward intention to purchase organic coffee

R Puspitasari \& T.E. Balqiah

Halal tourist destination: An Indonesian muslims' perspective

M. Fakhri \& N. Sobari

Consumer intention to adopt PayLater: An empirical study

A.S. Rachmawati \& R.D. Astuti

Promotional media development of MSMEs Bakmie Pulau Seribu

A.R. Lubis \& S. K. Widhaningrat

Improvement of dredging project planning with maturity model of lean project planning and control approach

K.N.P. Nugroho \& M.L. Singgih

The influence of destination image on tourist satisfaction and tourist loyalty: A case study of urban tourism in Semarang, Indonesia

G.P.M. Agung, S. Wijaya \& D.C. Widjaja

The liquidity contagion in the ASEAN-5

F.A. Pratiwi \& Z. Ananto

The development of marketing channels through social media, e-commerce and instagram promotion standard operating procedures of SMEs X

E.K. Prasetyo \& S.K. Widhaningrat

The expansion of marketing channel and creating company profile for a wedding

photography SME

N. Wiridyadewi \& H. Suhaimi

The effect of online promotion and travel motivation on intention to travel to ecotourism

destinations in Indonesia: The role of destination image as a mediating variable

S.F. Mulianto, H. Semuel \& S. Wijaya

Forming a financial statement of a construction company PT DMP

D. A. Rachma \& F. Ismaeni 
Use case points integrated to scrum framework for software development cost and effort estimations

L.N. Safitri \& M.I. Irawan

Impact of functional and nonfunctional values in adoption intention of Gesits electric motorcycle in Indonesia

F. Habibie \& M.G. Alif

Optimization of Instagram promotion and distribution using e-commerce platform for MSME Atkey

P. Nabila \& S. Hasnul

Competition in banking financial technology: The perspective of the demand side

I. Sadalia, F.N. Nasution \& A. Fauzi

Liquidity and credit risk in Indonesian Islamic banks A. Salahuddin, W.A. Perdana \& N.D. Hendranastiti

Oil price and cost of haij: The evidence from Indonesia

A. Salahuddin, W.A. Perdana \& N.D. Hendranastiti

Corporate social responsibility performance and banking soundness in Indonesia: Should the industry be more socially responsible?

R. Rokhim, W.A. Perdana \& M.R. Astrini

Oil price and airline company financial soundness

R. Rokhim, W.A. Perdana \& M. Robbani

Quality of channel integration, perceived fluency, and omnichannel service usage in the fashion industry moderating the role of gender

J.A. Nasir \& T.E. Balqiah

Financial feasibility analysis for outlet expansion of Masalalu café based on business coaching method

M. Sugiarto \& H. Suhaimi

The influence of non-interest income towards credit risk and loan spread in ASEAN-5

N.D. Novianti \& R. Rokhim

Credit growth and financial fragility in the ASEAN region

C.J. Hakim, R. Rokhim \& M. Aulia

The effect of corporate governance and financial factors on dividend payment

F. Asali, W.R. Murhadi \& B.S. Sutejo

Determinants of Mekaar's ultramicro credit default probability

N. Nurusshafa \& R. Rokhim

Developing a business strategic model using the Quantitative Strategic Planning Matrix (QSPM) approach for a fintech lending start-up based on lean start-up methodology

I. Gibranata \& M.L. Singgih

The influence of social media and social media advertising engagements on purchase intention in fashion product

H. Ulya \& Y. Alversia

Market reaction toward mandatory stock split in damascus security exchange

B. Kabouk \& I.A. Ekaputra 
The effect of Social Media Marketing Activities (SMMA) on brand awareness and customer response

D.F. Esma \& Nuryakin

The role of mediation attitude towards using in perceived usefulness relationship in behavioral intention

Effect of consumption value on behavioral intention through perceived beneficial image as a mediator

\section{S. Dianto \& Nuryakin}

Improvement of website and hotel exterior design based on business coaching method K. Nurfajri \& H. Suhaimi

Understanding banking ecosystem: A case study of national bank in Timor-Leste S. Noviaristanti \& F. Belo

The effect of perceived value and service quality on customer satisfaction program Jaminan Hari Tua (JHT) at BPJS Ketenagakerjaan Palembang branch office (Case study on salary recipient category participants)

V.A. Riefriani, Z. Wahab, M. Widiyanti \& M.S. Shihab

The effect of price and "free shipping throughout indonesia" tagline on buying interest in shopee app for undergraduate students at palembang campus, sriwijaya university N. Maria, Z. Wahab, M. Widiyanti \& M. Adam

The effect of price and promotion of induction stores on improving electricity sales in PT. PLN (PERSERO) UP3 Bangka in Celagen Island

Kgs. M.A. Amrullah, Z. Wahab, M. Widiyanti \& M.S. Shihab

Priority scale of the corporate culture of PT Krakatau Daya Listrik Daemulhay

An assessment of Melaka Halal hotel customer satisfaction using the SERVQUAL model W.P. Yin, N. Rashid, N. Ismail, M.S.M. Saad \& M.F. Kamarudin

Credit growth and bank soundness in the ASEAN region

C.J. Hakim, R. Rokhim \& F. R. Humaira

The impact of asset growth rate on future stock return of listed companies in the Indonesia

Stock Exchange (IDX)

D.S. Pramasti \& E. Rizkianto

Improving consumer satisfaction through the application of the lean hospital concept M. Isa, D. Handoyo \& I.S. Adji

The effect of destination images of tourist facilities and experiential marketing on loyalty of visitors to Taman Pintar Yogyakarta

B. W. Setyawibowo, Wiyadi \& Soepatini

Corruption perception index and locally generated revenue: Have they gotten better or worse? A case study in ten major cities in Indonesia

R. Rokhim, R.E.F. Nasution, A. Muchtar \& W. Thohary

The effects of brand value on brand loyalty toward cosmetics and skin care products:

Proactive and reactive reactions to sustainability

N. Kinanti \& Y. Alversia

Does the volatility of oil prices influence the transportation sector in ASEAN countries? 
The effect of service quality, price, and brand images on Grab Food customers loyalty in Palembang

A.F. Imanu, Z. Wahab, I. Andriana \& M. Widiyanti

The influence of brand image, price, and quality of products on cement purchasing decisions at Semen Baturaja (Persero), Ltd.

T. Ibrahim, Z. Wahab, M. Widiyanti \& M.S. Shihab

The effect of corporate social responsibility on corporate value with profitability as a variable moderation among coal mining subsector manufacturing companies listed in the Indonesia stock exchange

M. Widiyanti \& $P$. Wahyuni

Digital promotion media for small medium enterprises

D.W. Soewardikoen \& B. Prabawa

Good corporate governance and agency cost in Indonesia

Author index 


\section{Preface}

We are pleased to introduce the proceedings of the Third International Seminar of Contemporary Research on Business and Management (ISCRBM). This is an annual event of the Indonesian Master of Management Program Alliance (APMMI), held in the Master of Management Program, Indonesia University, Jakarta on November 27-29, 2019. Building Indonesian Talent Management was the conference theme, and three distinguished speakers were invited from professional and academic circles to share their knowledge and experience. The major goal of this event is as an opportunity to meet and develop networking between APMMI's members also to increase the quality and quantity of research publication in the management and business area.

Over 136 papers were presented during the conference and 84 selected papers were published in these proceedings. Papers were mostly authored by APMMI students and faculty members on various topics in operation management, marketing management, human resource management, finance, strategic management, and entrepreneurship. Another 7 authors came from outside Indonesia: Malaysia, Taiwan, Timor Leste, The Netherlands, and Switzerland,

Finally, we would like to record our thanks to the conference committee for their work, APMMI members who actively contributed to this event, and the Master of Management Program Indonesia University that nicely hosted this year conference. Without their support, the conference could not have been the success that it was. We also acknowledge the authors for their contribution. Hopefully, the success of the conference will continue next year when it is to be held in Surabaya.

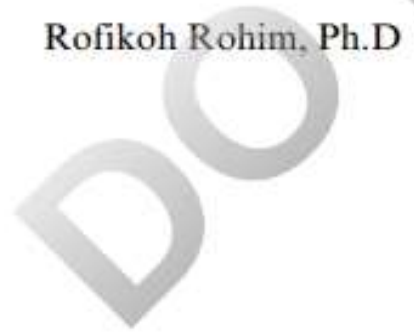




\section{Conference committee}

Chair: Rofikoh Rokhim, SE, SIP., DEA., Ph.D|Indonesia University

Co-Chair:

Dr. Nuryakin, SE., MM | Muhammadiyah University of Malang

Siska Noviaristanti, S.Si., M.T., Ph.D|Telkom University

Members:

Dr. Gancar Candra Premananto, SE., M.Si | Airlangga University

Dr. Werner Ria Murhadi S.E., M.M., CSA. | Surabaya University

Dr. Ahyar Yuniawan, S.E., M.Si| Diponegoro University

Ratna Wardani, MM | Indonesia University

Mohammad Tyas Pawitra | Telkom University

\section{Scientific committee}

Prof. Dr. Nuran Acur | Indonesia University of Glasgow, UK

Prof. Dr. John Vong | National University of Singapore

Mohd. Shamsuri Md Saat, Ph.D| University Teknikal Malaysia Malaka

Dr. Darwis Khudori | University of Le Havre, France

Prof. Fumio Itoh | President of ABEST21

Rofikoh Rokhim, SE, SIP., DEA., Ph.D | Indonesia University

Dr. Ahyar Yuniawan, S.E., M.Si| Diponegoro University

Dr. Dra. Kusuma Ratnawati, MM.,CFP | Brawijaya University

Marlina Widiyanti, SE, MM., Ph.D | Sriwijaya University

Dony Abdul Chalid, S.E., M.M., Ph.D |Indonesia University

Dr. Nuryakin, SE., MM | Muhammadiyah University of Malang

Dr. Gancar Candra Premananto, SE., M.Si | Airlangga University

Dr. Werner Ria Murhadi S.E., M.M., CSA. | Surabaya University

Nora Sri Hendriyeni, MM., Ph.D|PPM School of Management

Siska Noviaristanti, S.Si., M.T., Ph.D|Telkom University

\section{Advisory board}

Prof. Ari Kuncoro, S.E., M.A., Ph.D | Indonesia University

Ir. Dodie Tricahyono, M.M., Ph.D | Telkom University

Prof. Dr. Dian Agustia, S.E., M.Si., Ak| Airlangga University

Dr. Suharnomo, S.E., M.Si| Diponegoro University

Rizal Yaya, S.E., M.Sc., Ph.D., Ak, CA | Muhammadiyah University of Malang

Dony Abdul Chalid, S.E., M.M., Ph.D |Indonesia University

Dr. Putu Anom Mahadwartha, SE, M.M., CSA. | Surabaya University 


\title{
The effect of corporate governance and financial factors on dividend payment
}

\author{
F. Asali, W.R. Murhadi \& B.S. Sutejo \\ University of Surabaya, Indonesia
}

\begin{abstract}
This study aims to determine the factors that influence dividend payment policy. The study used data from all companies listed on the Indonesia Stock Exchange for five years and dividends for a minimum of three periods. This research used a panel data. The results showed that foreign ownership had a positive effect on dividend payment policy, domestic ownership, independent commissioners, while company growth had a negative effect on dividend payments. Meanwhile, the variables of board size, profitability, firm age, debt policy, and firm size did not affect dividends.
\end{abstract}

\section{INTRODUCTION}

Research on dividends shows two very different views of firm value. Baker and Weigand (2015) suggested that dividends are not relevant to firm value, and there is a possibility of value-destroying. Another perspective put forward by Baker and Weigand (2015) stated that dividends are an essential determinant in the value of a business entity. While Baker et al. (2011) said, "Despite a voluminous amount of research, we still do not have all the answers to the dividend puzzle".

Another theory by Najjar and Kilincarlsan (2016) said there is a positive effect of Corporate Governance on dividend payments. The theory indeed stated a positive relationship between the spread of ownership and dividend payments in developing countries. Najjar and Kilincarlsan's (2016) research results showed that foreign and state ownership have low involvement in dividend payments, while other ownership variables such as family involvement, domestic financial institutions, and minority shareholders do not affect the probability of dividend payments. Another study by Roy (2015) proposed that Corporate Governance variables, namely board size and the proportion of independent directors, have a significant impact on the dividend policy of business entities. The proportion of cash and cash equivalents to total assets used as a measure of business entity liquidity influences dividend policy and growth opportunities also have a positive effect on business dividend policy. Sigo and Selvam (2013) conducted a study to examine information on dividend policy from technology business entities listed on the Bombay Stock Exchange (BSE) with the result showed that factors of corporate governance and firm characteristics influence corporate business dividend policies. Firm size and profitability are the two factors that allow business entities to pay dividends.

Setiawan and Phua (2013), who conducted a study on Corporate Governance (CG) and dividend policy in Indonesia, proposed that the structure and procedures in the board of commissioners and the lack of disclosure practices have a negative influence on dividend policy. From the fundamental factor test, it was found that growth and profitability have a positive effect on dividend policy, while firm size did not. Meanwhile, Murhadi and Wijaya (2011), in their research, showed that only the life cycle stages of a business entity and profitability affected the dividend policy.

Based on the background as mentioned above, a research question was formulated: Is there any influence between board size, foreign ownership, domestic institutional ownership, 
independent commissioner, profitability, growth, debt policy, firm age, and firm size on dividend payments?

\section{RESEARCH METHODS}

This study used all business entities in all sectors listed on the Indonesia Stock Exchange (IDX). The dependent variable in this study is dividends measured by dividing dividends per share by the current stock price. The independent variable of Board size in this study was measured by the number of boards of commissioners in a business entity. Foreign ownership was measured by the percentage of shares of a business entity $i$ owned by a foreign business entity, or a foreign financial institution, or a foreign citizen in t period. Domestic institutional ownership was measured using the amount of the percentage of shares of a business entity $i$ owned by a legal entity or a financial institution in $t$ period. Independent commissioners were measured by comparing the total number of independent commissioners to the total board of commissioners. Profitability was measured using Return On Assets (ROA). Growth was measured using total assets this year, minus total assets of the previous year divided by total assets of the previous year. Debt policy was measured using a debt ratio (DR). Firm age is the length of a business entity standing until the time of research. Firm size was measured using the logarithm of total assets.

\section{RESULTS AND DISCUSSION}

After carrying out the classical assumption test and the Chow test as well as the Haussmann test, the research model to be analyzed using the fixed-effect model is shown in Table 1.

In Table 1, it can be seen that the coefficient of the board size variable shows insignificant negative results, while the initial hypothesis was that the board size has a positive effect on dividend payments. The effect is insignificant because the board size in this study was measured using the number of commissioners, where the function of the commissioner is as a supervisor of a business entity. Those responsible for determining the amount of the dividend are directors related to the Residual Dividend Theory, a theory that states dividends are paid if there are residual earnings after the business entity meets its investment needs. This insignificant negative result is consistent with the results of Roy's study (2015), which stated that a negative board size is not significant to the Dividend Yield Ratio (DYR).

The foreign ownership variable is significantly positive; while the initial hypothesis was that the foreign ownership variable has a negative effect on dividend payments. The positive influence of foreign ownership variable on dividend payments can be explained through research

Table 1. Results.

\begin{tabular}{llll}
\hline Dependent Variable: Dividend Yield & & \\
\hline Independent Variables & Coefficient & Probability & Hypothesis \\
\hline Board Size (BS) & -0.0036 & 0.1113 & Positive \\
Foreign Ownership (Foreign) & $0.0256^{* *}$ & 0.0497 & Negative \\
Domestic Institutional Ownership (Dom) & $-0.0248^{*}$ & 0.0656 & Positive \\
Independent Commissioner (Ind) & $-0.1005^{* * *}$ & 0.0000 & Negative \\
Profitability (Prof) & -0.0429 & 0.1538 & Positive \\
Growth (Gwth) & $-0.0014^{*}$ & 0.0601 & Negative \\
Debt Policy (Debt) & 0.0272 & 0.1115 & Negative \\
Firm Age (Age) & -0.0004 & 0.7927 & Positive \\
Firm Size (Size) & -0.0083 & 0.6292 & Positive \\
\hline
\end{tabular}

Note: *: significant at $10 \%, * *$ : significant at $5 \%, * * *$; significant at $1 \%$ 
by Wiranata and Nugrahanti (2013), which stated that the increasing number of foreign parties investing their shares in a business entity would improve the performance of the business entity invested in its shares. This happens because foreign parties that invest their shares have a good management system, technology and innovation, expertise, and marketing that can bring positive influence to business entities. In a business entity with higher foreign ownership, the foreign party as the majority shareholder will commonly appoint foreigners to serve as the board of commissioners or the board of directors; thus the alignment between the objectives to maximize the performance of the business entity will be achieved because of similar principle between foreign shareholders and management that is also occupied by the foreigners as part of the management of a business entity. Thus, the better performance of business entities will have a positive influence on the amount of dividends paid.

The domestic institutional ownership variable is significantly negative; while the initial hypothesis was that the variable of domestic institutional ownership has a positive effect on dividend payments. The negative influence of domestic institutional ownership variable on dividend payments is related to the Tax Preference Theory, a theory that states dividends received by shareholders will be taxed higher than the tax on capital gains; thus, this can make investors prefer profits earned by business entities retained for investments that will produce capital gains in the future rather than paid in the form of dividends for tax reasons. This theory indeed states that a low dividend payout will maximize the value of a business entity, and shareholders prefer this. This study is consistent with Abdesalam's (2008) and Ginting (2015) research, which scrutinized that domestic institutional ownership investors prefer capital gains if the current tax on dividend payments is higher than the tax for capital gains. Furthermore, taxes on dividend income are paid when dividends are received, while tax payments on capital gains are postponed until the shares are sold. Therefore, the effective tax rate on dividend income is greater than the tax on capital gains. This causes investors to prefer retained earnings used for investment. Moreover, it can be concluded that the higher the level of domestic institutional ownership, the lower the dividends paid to shareholders will be. Domestic institutional ownership variable that shows significant negative results is consistent with the results of research by Najjar and Kilincarslan (2016), which proposed that domestic institutional ownership is significantly negative for the DPR and DYIELD.

The independent commissioner variable, which shows a significant negative result, is in line with the initial hypothesis. The negative influence of the independent commissioner variable is in accordance with the results of Murhadi and Wijaya's (2011) research, which showed that the board of commissioners from independent parties could be more effective in conducting supervision. Thus, the dividend function as a signal will decrease. As a result, dividends will also decline.

The negative profitability variable is not significant; while the initial hypothesis was that the profitability variable has a positive effect on dividend payments. The insignificant influence can be explained by scientific research and Asandimitra (2014), which showed that most business entities on the Stock Exchange have long been established and are in the maturity stage so that profitability is not considered in decision making in dividend payments. Business entities tend to prioritize the source of funds obtained used for the development of business entities so that business entities do not pay attention to dividend payments. This result is consistent with the research of Lopolusi (2013) explaining that profitability does not always affect dividend payments, especially in business entities that have long been established and are in the maturity stage, these business entities already have many profit reserves that can be used either for reinvested or distributed as dividends. This causes profitability not to affect dividend payments.

The growth variable, which shows a significant negative result, is in accordance with the initial hypothesis expectation. The negative effect of the growth variable is consistent with the results of Murhadi and Wijaya's (2011) research that said business entities with higher growth would require a significant source of funding in order to finance their activities. Thus, the business entity tends to hold its profits to finance the development of the business entity's activities rather than distribute them in the form of dividends. 
The positive debt policy variable is not significant. The insignificant influence can be explained by using the Pecking Order Theory, where this theory states that in order to cover the investment needs, internal funding is a priority, so the size of the debt does not affect the amount of dividends because the business entity prioritizes internal. This result is consistent with the results of Saptari's research (2016), which stated that a business entity should not use too much debt because it will affect the capital structure of the business entity.

The firm age variable has no effect on dividend payment. The effect is not significant because the performance of a business entity does not depend on how long the business entity has been established. Newly established business entities can adapt and learn from the experience of long-standing business entities in both financial and operational strategies. Long-standing business entities may prefer to stay in the safe phase and continue to develop their business in terms of research and development. Therefore, it can be concluded that the age of the business entity does not affect the performance of the business entity.

The firm size variable does not affect dividend payment. The effect is not significant because a business entity that has an enormous asset may not necessarily have an excellent performance, as explained in research by Nuringsih (2005) that said a business entity with a significant asset tends to use debt or shares when doing expansion. Under these conditions, the business entity requires a high cost in financing its activities so that if the business entity pays a dividend, it will certainly add to its obligations. Therefore, it can be concluded that in determining the dividend payment, the business entity does not pay too much attention to its total assets.

\section{CONCLUSION}

Based on the test results, it was obtained that domestic institutional ownership and growth variables have a significant effect on the direction of the negative relationship to dividend payments. While the foreign ownership variable has a significant effeet on the direction of a positive relationship, and the independent commissioner variable has a significant effect on the direction of a negative relationship. Additionally, variables of board size, profitability, firm age, debt policy, and firm size do not affect dividends.

This research can be used as a recommendation for further research. This study has limitations, namely the number of observations that are only on the Indonesia Stock Exchange, and variables that do not cover all. For further research, it is expected to examine a broader scope such as all business entities in ASEAN as well as add other business entity factors that have not been examined in this study, such as audit committee, family ownership, audit type, and state ownership.

\section{REFERENCES}

Abor, J., dan V. Fiador, 2013, Does Corporate Governance Explain Dividend Policy in Sub-Saharan Africa?, International Journal of Law and Management, Vol. 55, No.3: 201-225.

Ginting, J., 2015, Pengaruh Good Corporate Governance terhadap Kebijakan Dividen, Studi Empiris pada Perusahaan Manufaktur yang Terdaftar di BEI Tahun 2011-2013, Skripsi, Universitas Diponegoro.

Lopolusi, I., 2013, Analisis Faktor Faktor yang Mempengaruhi Kebijakan Dividen Sektor Manufaktur yang Terdaftar di PT Bursa Efek Indonesia Periode 2007-2011, Jurnal Ilmiah Mahasiswa Universitas Surabaya, Vol. 2: 1 .

Murhadi, W.R., dan L.I. Wijaya, 2011, Studi Pengaruh Good Corporate Governance, Analyst Coverage, dan Tahapan Daur Hidup terhadap Kebijakan Deviden, Jurnal Manajemen dan Bisnis, Vol. 10, No.1: 111-126.

Najjar, B., dan E. Kilincarslan, 2016, The Effect of Ownership Structure on Dividend Policy: Evidence from Turkey, Corporate Governance, Vol.16, No.1: 135-161. 
Nuringsih, K., 2005, Analisis Pengaruh Kepemilikan Manajerial, Kebijakan Hutang, ROA, dan Ukuran Perusahaan terhdap Kebijakan Dividen, Jurnal Akuntansi dan Keuangan Indonesia, Vol. 2, No. 2: $103-123$.

Roy, A, 2015, Dividend Policy, Ownership Structure and Corporate Governance: An Empirical Analysis of Indian Firms, Indian Journal of Corporate Governance, Vol. 8, No.1: 1-33.

Setiawan, D., dan L.K. Phua, 2013, Corporate Governance and Dividend Policy in Indonesia, Business Strategy Series, Vol. 14: 135-143.

Sigo, M.O., dan M. Selvam, 2013, Corporate Governance and The Determinant of Dividend Policies of Information Technology Companies in India, Disertasi, Tiruchirappall University.

Wiranata, Y.A., dan Nugrahanti, Y.W., 2013, Pengaruh Struktur Kepemilikan terhadap Profitabilitas Perusahaan Manufaktur di Indonesia, Jurnal Akuntansi dan Keuangan, Vol. 15, No. 1: 15-26. 


\title{
Good corporate governance and agency cost in Indonesia
}

\author{
A.P.K. Hadi, W.R. Murhadi \& B.S. Sutejo \\ Universitas Surabaya, Indonesia
}

\begin{abstract}
This study aims to determine the effect of good corporate governance on agency costs in Indonesia. Good corporate governance in this study is represented by the size of the board of commissioners, the existence of independent commissioners, managerial ownership, and external ownership. Agency cost in this study used the proxy asset utilization ratio, where the relationship is the opposite. This study used a sample of non-financial companies listed on the Indonesia Stock Exchange. The results show that the size of the board of commissioners and the existence of independent commissioners has a positive effect on asset utilization ratio and a negative effect on agency cost. This study also gives managerial ownership results in a negative effect on asset utilization ratio and a positive effect on agency cost. While external ownership does not affect agency cost.
\end{abstract}

\section{INTRODUCTION}

The agency problem is always an interesting topic to study, especially in developing countries where law enforcement is still weak. Fama \& Jensen (1983) in Garanina \& Kaikova (2015) stated that the agency and corporate governance problems are two related matters, thereby to minimize agency problems; a company must ensure that there are effectiye control procedures within the company. Meanwhile, to reduce agency costs resulting from the conflict, the company must have an alignment between the interests of the agent and the principal (Garanina \& Kaikova, 2015). The implementation of good corporate governance is an important part because it can reduce the agency cost of a company. Garanina \& Kaikova (2015) argued that agency problems that occur in companies could lead to high agency costs. Meanwhile, Khan et al. (2016) stated that corporate governance is considered as a mechanism that can protect minorities and expropriation by managers by emphasizing legal mechanisms. If the corporate governance mechanism is not implemented or does not function well within the company, then it can reduce the trust of shareholders and the value of the company will also decrease. Some studies discuss the effect of corporate governance on agency costs as measured by using the asset utilization ratio as the dependent variable. Garanina \& Kaikova (2015) conducted a study of corporate governance and agency costs by using several sample companies in the USA, Russia, and Norway. The results of the study indicate that leverage and firm size have a positive effect on asset utilization, while commissioner size harms asset utilization. Meanwhile, Ibrahim \& Samad (2011) conducted a study on corporate governance and agency costs for family companies and non-family companies registered in Malaysia. The results of this research show that duality and commissioner size have a positive effect on asset utilization while leverage and firm size harms asset utilization. Other researchers, Singh \& Davidson (2003) researched agency costs, ownership structure, and corporate governance mechanisms using objects of large companies registered in the USA. From the results of this research, it is known that managerial ownership, external ownership, and firm size have a positive effect on asset utilization, while commissioner size and leverage negatively affect asset utilization. Khan et al. (2016) researched corporate political connections, agency costs, and audit quality using data from non-financial companies registered in Bangladesh. The results of this research show that commissioner independence, leverage, firm size, and firm age have a positive effect on 
asset utilization. This study will use eight independent variables, namely commissioner size, commissioner independence, managerial ownership, external ownership, leverage, firm size, firm age, and dividend yield. This study uses agency costs as measured through asset utilization ratio as the dependent variable. The relationship between agency cost and asset utilization ratio is inversely related.

\section{RESEARCH METHODS}

This study used a sample of non-financial sector business entities listed on the Indonesia Stock Exchange (IDX) for 5 years, with a total observation of 1,550 years of observation. The method used in conducting this research was regression analysis with panel data. The dependent variable in this study was agency cost, which was measured using asset utilization. The independent variables were commissioner size, commissioner independence, managerial ownership, external ownership, while the control variables were leverage, firm size, firm age, and dividend yield. Agency cost was measured through the asset utilization ratio, which is the company's total sales divided by the total assets owned by the company. Commissioner size is the number of existing members of the board of commissioners. Commissioner independence is the proportion of independent commissioners in a board of commissioners. Managerial ownership is a manager who has a stake in the company or a manager who is also a shareholder in the company. External ownership is a percentage of the total share ownership that has $5 \%$ or more of the shares issued by the company and is not related to management in the company and not institutional. Leverage calculates the total short-term and long-term liabilities of the company's total assets. Firm size is the total capitalization or number of assets owned by the company. Firm age is the age of a company from its inception until the current period. The dividend yield is the dividend per share divided by the market price of shares.

\section{DISCUSSION}

Commissioner size variable test results in Table 1 show that the increasing number of commissioners in a company will increase the utility of assets, and have an impact on reducing agency costs. Pearce \& Zahara (1991) in Garanina \& Kaikova (2015) argued that a more significant number of commissioners have a positive impact because it can provide a better recommendation, advice

Table 1. Regression test results (asset utilization ratio).

\begin{tabular}{llll}
\hline Variable & Coefficient & t-Statistic & Probability \\
\hline C & 8.654562 & 13.94683 & 0.0000 \\
COM_SIZE & 0.005669 & 11.67105 & $0.0000^{* * *}$ \\
COM_IND & 0.040007 & 4.986310 & $0.0000^{* * *}$ \\
M_OWN & -0.121649 & -1.804447 & $0.0714^{*}$ \\
EXT_OWN & -0.128215 & -1.620534 & 0.1054 \\
LEV & 0.074982 & 2.721168 & $0.0066^{* * *}$ \\
F_SIZE & -0.220378 & -21.85657 & $0.0000^{* * *}$ \\
F_AGE & -0.045189 & -2.838332 & $0.0046^{* * *}$ \\
DIV_YIELD & 0.016592 & 0.185382 & 0.7320 \\
R-Squared & & & 0.993800 \\
Adjusted R-Squared & & & 0.992205 \\
F-statistic & & & $622.9414 * * *$ \\
\hline Note *: significance at $10 \%$ & & \\
**: significance at 5\% & & \\
****: significance at $1 \%$ & & &
\end{tabular}


when making decisions, and improve company image to reduce agency problems and agency costs. Law of the Republic of Indonesia about Limited Liability Company in 2007 article 108 paragraph 1 states that the board of commissioners has the function to supervise the company's management policies in general, both regarding the company or the company's business, and provide advice to the company's board of directors. Thus, the welfare of the shareholders will increase and can minimize the agency problems that exist in the company. Commissioner independence variable test results in Table 1 shows a significant positive effect on asset utilization ratio. In this case, the more number of independent commissioners in the company is, the fewer agency costs will be. The results of this study are in accordance with Ibrahim \& Samad (2011), Henry (2009), and Khan et al. (2016), where the more commissioner independence in the company is, the smaller agency cost will be because monitoring in the company will increase and also the management of assets is more efficient (Shael et al., 2016). Whereas, Weisbach (1978) in Shael et al. (2016) stated that the existence of an independent commissioner could monitor managers effectively because it is more neutral than the commissioners in the company and has no personal interests to reduce agency costs.

The results of managerial ownership variables in Table 1 show a significant negative effect on asset utilization ratio. In this case, the more managerial shareholding in the company is, the higher agency costs will be. The results of this study can be explained by the increasing managerial ownership will increase agency costs, especially related to minority shareholders. The external ownership test results in Table 1 show no significant negative effect on asset utilization ratio and agency cost. This can be seen from the average non-financial companies in Indonesia that are relatively small in share ownership by external parties, even many companies do not have external ownership in their companies. Also, the role of external share ownership itself is ineffective because the external party will not have the time or expertise to act as an effective monitor in the company (Doukas, Kim, \& Pantzalis, 2000 in Fauzi \& Locke, 2012). The results of the leverage variable test in Table 1 show that debt has a significant positive effect on asset utilization ratio. In this case, the greater company's debt can reduce agency costs. Ang et al. (2000) and Fleming et al. (2005) in Garanina \& Kaikova (2015) argued that the use of higher leverage would be more efficient because it could prevent unnecessary expenses from the company and encourage managers to operate the company more efficiently so that agency costs would decrease. Besides, Jensen (1986) in Shael et al. (2016) uttered that if the company's debt increases, the manager will be required to manage assets more efficiently so that the assets being managed are also sufficient to pay for new debt additions. In other words, the addition of debt, which affects the company's debt to asset ratio, has a positive impact on the management of company assets so that it will reduce agency costs in the company, Firm size yariable test in Table 1 show a significant negative effect on asset utilization ratio. Doukas et al. (2000) in Garanina \& Kaikova (2015) found that the greater the size of the company, the higher the agency cost, because in the company, there is a more comprehensive and more diverse organizational structure, thereby larger companies will tend to cause conflict. Furthermore, Henry (2006) also stated that the larger the size of the company, the more vulnerable the company to agency problems that will instigate agency costs. Firm age variable test results in Table 1 show that there is a significant negative effect on asset utilization ratio. Shael et al. (2016) proposed that as a company becomes older and its culture is rigid, the company will find it difficult to follow and implement innovations demanded by market developments, compared to younger companies. Because of this, the efficiency of managing company assets will decrease and have an impact on sales or income, which also decreases, thus increasing agency costs.

\section{CONCLUSION}

The results showed that the size of the board of commissioners, the existence of independent commissioners, and debt would be able to reduce agency costs. The higher the number of commissioners in the company, the tighter the supervision, which will decrease the agency costs of the company. Likewise, the existence of independent commissioners in the company 
will decrease the company's agency cost. Debt also has an impact on better supervision, so agency costs fall. This study also found that a greater amount of managerial shareholding in a company would increase agency costs. This study also obtained the results of the size and age of the company can increase agency cost.

\section{REFERENCES}

Ang, J.S., Cole, R.A. \& Lin, J., 2000, Agency costs and ownership structure, Journal of Finance, 55(1): 81-106.

Fauzi, dan Locke, 2012, Board Strucutre, Ownership Structure and Firm Performance: A Study of New Zealand Listed-Firms, Asian Academy of Management Journal of Accounting and Finance, Vol. 8 no. 2 : 43-67.

Garanina, T., dan Kaikova, E., 2015, Corporate Governance Mechanisms and Agency Costs: CrossCountry Analysis, Journal of Corporate Governance, Vol. 16: 347-360.

Henry, D., 2009, Agency Costs, Ownership Structure and Corporate Governance Compliance: A Private Contracting Perspective, Journal Pasific Basin Finance, Vol. 18: 2446

Ibrahim, H., dan Samad, F.M.A., 2011, Corporate Governance and Ageney Costs, Journal International Corporate Governance, 109-130.

Khan, Mihret, Muttakin, 2016, Corporate Political Connections, Agency Costs and Audit Quality, International Journal of Accounting \& Information Management, Vol. 24: 4, pp.357-374.

Murhadi, W. R., 2008, Studi Kebijakan Dividen: Anteseden dan Dampaknya Terhadap Harga Saham, Jurnal Manajemen dan Kewirausahaan, Vol. 10 no. 1:1-7.

Shael, E., Murhadi, W.R., Utami, 2016, Pengaruh Ownership Structure, Free Cash Flow, dan Corporate Governance Terhadap Biaya Keagenan, Working Paper, Universitas Surabaya.

Singh, M., dan Davidson, W.N., 2003, Agency Costs, Ownership Structure and Corporate Governance Mechanisms, Journal of Banking and Finance, Vol. 27: 793-816. 